\title{
Implementation of Computer-assisted Learning in High School: Teachers and Students' Perspective
}

\author{
Mochamad Kamil Budiarto \\ Department of Educational Technology, Sebelas Maret University \\ Email: kamiltp@student.uns.ac.id \\ Triana Rejekiningsih \\ Department of Educational Technology, Sebelas Maret University \\ Email: triana_rizq@staff.uns.ac.id \\ Sudiyanto \\ Department of Educational Technology, Sebelas Maret University \\ Email: soeddie.fkipuns@gmail.com
}

Received: 09 February 2021; Accepted: 07 March 2021; Published: 08 August 2021

\begin{abstract}
This study intends to identify school readiness in implementing information and communication technology (ICT) assisted learning, especially the use of computers. This research applied descriptive quantitative. The research samples used were subject teachers and second grade of high school students. The data collection technique employed a survey method, carried out with a random questionnaire distribution to the research sample. The results of the research sample responses were analyzed quantitatively by interpreting the percentage. Information was obtained that schools were basically "ready" to implement ICT-assisted learning. Student responses' results showed that $55 \%$ of students "agreed" that the school had a computer laboratory, meanwhile $41.7 \%$ of students stated that they had sufficient ability at operating computers. The teachers' responses showed that the school already has supported the computer-assisted learning process and they are interested in integrating ICT in classroom activities. This research can be a basis for educators in identifying the extent to which students, teachers and school facilities are prepared to support computerbased learning. Given that computers are one of the technologies that can be used for learning activities and have been empirically proven to be able to make it easier for students to understand learning material.
\end{abstract}

Index Terms: Computer-assisted learning, school readiness, ICT facilities, interactive, multimedia, learning.

\section{Introduction}

Along with the times, various kinds of innovations and changes that occur rapidly require the education system to immediately adjust and innovate learning implementation, one of which is by utilizing technology for learning activities [1]. Besides, there is a demand for the mastery of knowledge and skills that students must possess to become adaptive individuals [2]; therefore, Information and Communication Technology (ICT) is a significant factor in being able to adapt to current conditions [3]. Information technology's role and function influence the education and learning system [4]. The development of ICT will facilitate an effective teaching and learning process. Still, the successful implementation of this ICT will be influenced by the learning environment, such as schools, campuses, and communities [5,6]. Some experts argue that applying information technology to the education system, especially in implementing learning process, will: a) improve education quality by providing motivational stimuli to students; b) increase the individual learning's efficiency and intensity; c) be able to change the educational process from passive to active learning; d) change the learning culture and make the teacher a learning facilitator, not as the only learning resource center; and d) improve the quality of computer-based assessments [7,8,9].

On the other hand, the whole world is plagued by problems in the health sector, namely the spread of COVID-19, demanding each country's government adapt to these conditions and circumstances. The COVID-19 pandemic period requires an appropriate learning model for students, a form of independent education and technology-assisted learning [10]. Referring to the circular letter (SE) of the Minister of Education and Culture Number 2 of 2020 concerning the prevention of coronavirus disease (COVID-19) in the education unit, it is instructed to the local governments to carry out learning at home for three regional categories and make online learning guidelines [11]. 
The implementation of online learning as stipulated in the circular requires a pattern to convey lesson material and information so that students and teachers understand that they must be able and motivate themselves to find the information they need and have responsibility for what they need. It is necessary to have learning models, media, and learning tools to improve student achievement. For instance, one of the media that can be used in learning process in high schools is ICT because most high school students are already familiar with technology, especially computers [12].

Developing ICT, particularly in an educational institution, should receive more attention from the government. Students and teachers are strived to continuously update their knowledge [13]. When students have a positive perspective and acknowledge the challenges of the world that life later will not be separated from IT \& ICT, then the use of ICT at the school level becomes one of the most valuable options to be implemented [14].

The scope of the use of technology for the learning process must be a major factor in facilitating learning for formal and non-formal education, with the computers as hardware that can be utilized [15,16]. In some cases, in "favorite" schools, computers have become an essential part of the learning process. Besides, the use of computers for this learning process will be more optimal with internet supports. It will require students to be more active in optimizing information sources containing subject matter sourced from the internet [17]. Since 2017, the Indonesia's government has implemented a Computer-Based National Examination, which showed that Indonesia's education system is inseparable from the use of technology and technological developments. The use of ICT can improve teachers' quality and professionalism; all teachers must compete to use the latest information technology so that ICT can be integrated into the teaching and learning process $[18,19]$.

ICT development is an indication of educational progress, which leads to the use of technology in accessing information to increase knowledge and gain competence. Various kinds of learning approaches that use technology have been developed and modified in the form of teaching programs using computer media or CAI (Computer-Assisted Instruction), such as simulations, exercises, practices or an audio-visual form [20], visual-based media [21], and interactive learning (multimedia) programs [24,25], which as a whole, the implementation of several models of these approaches must be supported by computer devices. Even though it is stated that the use of ICT in the learning process can provide a new perspective on teaching students' effectiveness, teachers still need to attend various professional training to integrate available technology into the learning process [24].

In line with some of the information presented, technology has become an essential object for advancing education quality nationally. The benefits and purposes of using technology are as a means to develop learning resources, materials, and information so that students are more interested in participating in learning activities [27,28], give students the freedom to access subject matter and information according to their learning style. Hence, the material or information presented should pay attention to students' characteristics [27]. Computer-based technology as a type of technology that is quite familiar among educators and students can be visualized in the form of interactive learning media[28,29,30], which is expected to be able to minimize differences in perceptions of an explanation of information or subject matter.

The implementation of computer-based technology in the learning process cannot be separated from several factors; among several critical external factors that affect the implementation of computer-based technology in the learning process are students' social conditions, student demographics, student age, information disclosure, school environment, and reform in the field of education itself, as a subject that drives computer-assisted learning [31,32].

As one of the factors influencing technology implementation in education, the school environment plays a role in the readiness of supporting facilities, such as computer laboratories and other supporting facilities [33]. School readiness in facilitating learning activities with computer-based interactive media is the key to successfully implementing learning using computer technology [34,35]. Therefore, it is deemed necessary to identify and assess school readiness level as one of the steps to identify technology-assisted learning needs. By knowing the readiness level, schools can determine policies or strategies regarding computer-assisted learning.

School readiness in implementing computer-based technology is a significant factor in applying technology in the learning process. Assessment of the learning process's readiness supported by computer-based technology and other digital technologies is also essential because there are often various implementation obstacles. Some of the challenges experienced include consistency of use, digital literacy, limited human resources, competence in operating computers, and organizational learning [36]. The benefits obtained from the readiness assessment results are identifying the supporting and inhibiting factors for educational institutions, in this case, schools, to effectively implement technologybased learning resources [37].

Further, the Electronic Learning Readiness (ELR) model is designed to facilitate the process of obtaining information needs to implement digital technology-assisted learning, such as computers. The ELR model developed by Hashim \& Tasir [36] has several indicators: student readiness, teacher readiness, information technology-based supporting infrastructure, management support, and school culture. Besides, another ELR model proposed by Oketch et al. [38] revealed other factors that need to be considered for preparing computer technology-based learning; some of these factors are technology, culture, and materials or information. In line with this, Msila [39] \& Azimi [40] stated several other factors that can be used to obtain information related to the implementation of digital technology-based learning, including regarding ICT infrastructure, human resources, learning materials, and the availability of supporting 
infrastructure owned by schools. However, student acceptance of technology-assisted learning should not be ruled out because, as subjects in the learning process, students need to get the necessary facilities [41,42].

From the various literature that have been described, the successful implementation of computer-assisted learning in an institution is primarily influenced by the educational institution's readiness, in this case, the schools. Besides, several factors influence schools' readiness to implement technology in the learning process. This study aims to obtain information about school readiness in the context of implementing computer technology-assisted learning. The availability of school infrastructure, teacher readiness, and student competence in operating computers were employed as school readiness indicators to implement computer-assisted learning. Some of these indicators are critical points for successful learning with the help of computer technology.

Therefore, this research aims explicitly to obtain information regarding 1) the availability of supporting facilities owned by the school, 2) the teacher readiness in implementing ICT, 3) the students' competence in operating computers, and 4) student acceptance in the context of implementing learning assisted by information and communication technology (ICT) in the format of an interactive multimedia program or application.

In addition to the stated objectives, this research has limited scope where this research is limited to identifying various indicators that indicate a school's readiness to implement computer-assisted learning, based on the views of teachers and students.

\section{Method}

This research is descriptive quantitative research. Data collection was carried out by survey methods [43]. The data collection technique employed a questionnaire as a research and development instrument. Compared to other methods (direct observation, experiment), surveys produce a wider range of information. Surveys are effective for generating information on socio-economic characteristics, attitudes, opinions, motives, etc. In addition, the questions on the survey method are easy to manage, the data tend to be reliable, and relatively simple to analyze, cite and relate the data obtained by the survey method [44].

The questionnaire used was a five-scale questionnaire, with the statement details of strongly agree, agree, do not know/neutral, disagree, and strongly disagree for students questionnaire. The research instrument was adopted from the theory of the Electronic Learning Readiness (ELR) model put forward by Hashim \& Tasir [36], Msila [39] \& Azimi [40].

This study's populations were teachers and students at Senior high school. Meanwhile, the samples were chosen randomly, comprising four craft and entrepreneurship subject teachers and 60 students at senior high school. The data collected based on the survey results were analyzed quantitatively using percentages and the mean to obtain accurate information about school readiness in implementing computer-assisted learning.

\section{Results and Discussion}

\section{A. Results}

The questionnaire data results were processed to get the percentage value of each aspect. Based on these results, each aspect of the school readiness factor's percentage value is shown in this section. These results represent the school readiness level. The following conveys the effects of school readiness in utilizing digital technology, especially computers, for the learning process in terms of teacher readiness.

Table 1. The Teachers' Readiness in ICT Implementation

\begin{tabular}{|c|c|c|c|}
\hline \multirow[t]{2}{*}{ Items } & \multicolumn{3}{|c|}{$\begin{array}{c}\text { Response } \\
\text { Percentage }(\%)\end{array}$} \\
\hline & Agree & Uncertain & Disagree \\
\hline $\begin{array}{l}\text { Are you using computer-based learning media (Computer Assisted } \\
\text { Instruction) in the learning process? }\end{array}$ & $50 \%$ & $50 \%$ & \\
\hline $\begin{array}{l}\text { Regarding supporting learning facilities, your school teaches you the } \\
\text { supporting tools for computer-based learning media... }\end{array}$ & $100 \%$ & & \\
\hline $\begin{array}{l}\text { I think that computer-based learning media in the learning process } \\
\text { (Computer Assisted Instruction) is interesting... }\end{array}$ & $100 \%$ & & \\
\hline
\end{tabular}

Based on the data shown in Table 1, the teachers' responses represented that the teachers had a readiness and an open perspective towards the use of computer-based digital technology for learning activities at school. Information obtained from the questionnaire results given to the teachers revealed that $100 \%$ of the teachers agreed that computerassisted learning media were very interesting for the learning process. It was supported by the school's infrastructure, where $100 \%$ of teachers stated that the school was equipped to use ICT in the learning process.

The next aspect was about the availability of supporting facilities owned by the school. This question gave to 60 students. Student responses indicated that they agreed or knew that the school had a computer laboratory and LCD projector that could be used during the learning process. As many as 55\% of students stated 'agree' that the school had 
complete ICT facilities to support the learning process, while $16.7 \%$ of students stated, 'do not know', and $13.3 \%$ of students stated 'disagree' that the school had complete ICT facilities and could be used to support the learning process. The teachers' statements supported it during the interview, stating that the school has already had a computer laboratory, with 60 units of computers divided into two rooms. The teachers explained that not all subjects used computers, so not all students realized that a computer laboratory could be used for the learning process. The following shows a graph regarding the data on the availability of supporting facilities owned by the school. The graph is in Figure 1.

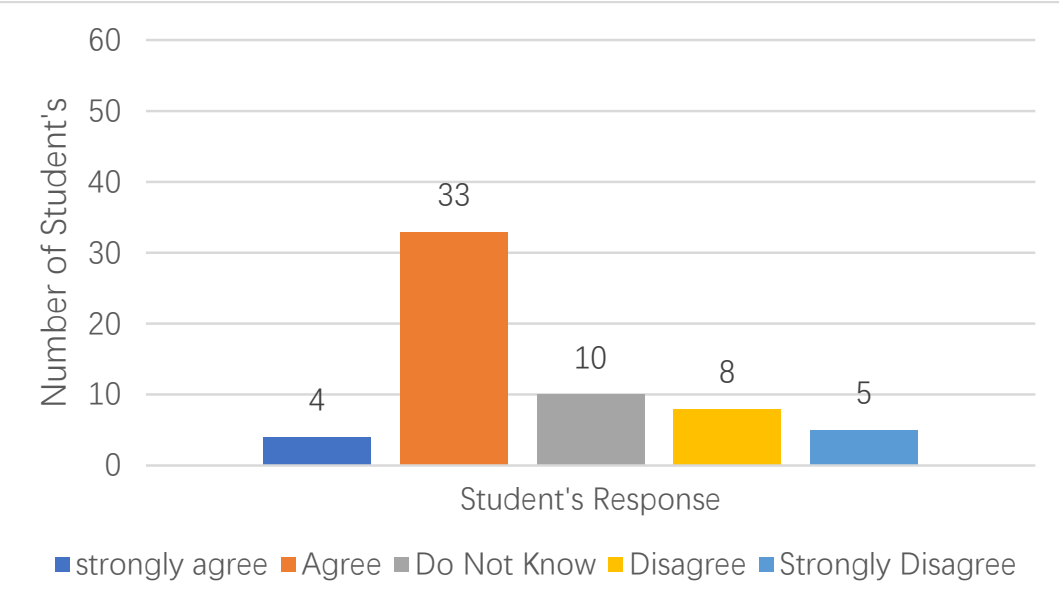

Fig 1. Availability of Facilities Owned by School

The use of ICT to support the learning process requires ability or expertise in the operation itself. Thus, information is needed about students' abilities as learning subjects in operating ICT, including smartphones, computers, and laptops. The students' response results showed that $18.3 \%$ of students had 'very good' skills in operating computers, and $31.7 \%$ of students had 'good' computer operating skills. It was followed by $41.7 \%$ of students who had 'sufficient' computer operation skills, and $8.3 \%$ of students were known to have 'not-good' competence in operating computers. The survey results are displayed in Figure 2 below.

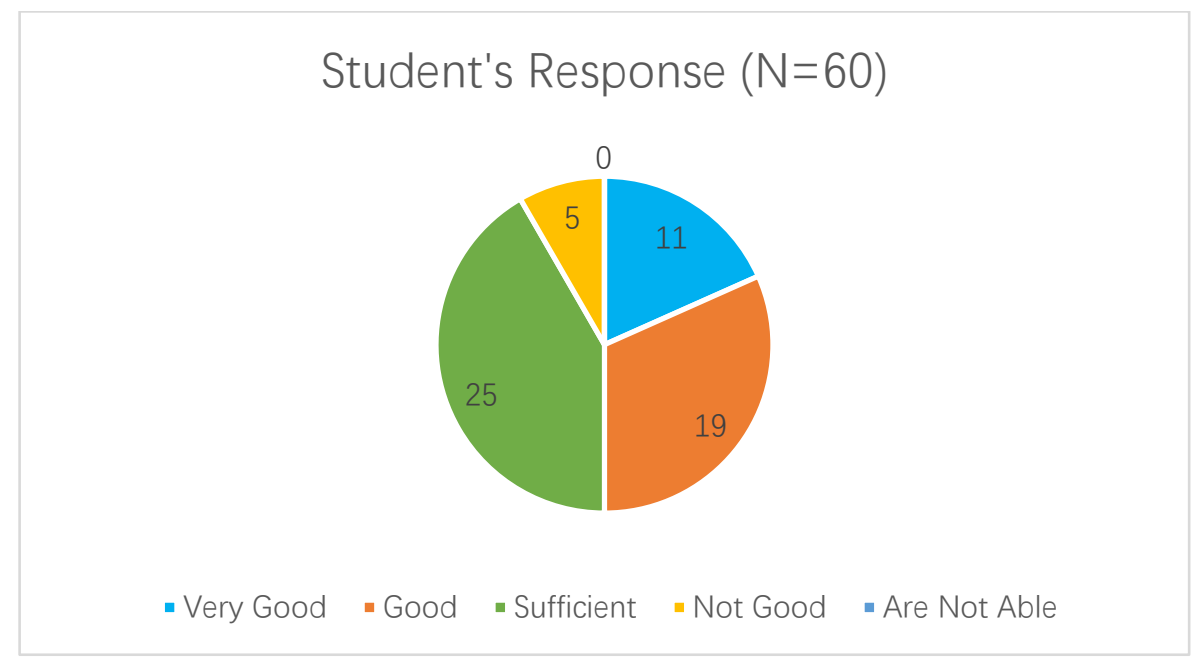

Fig 2. Student Computer Operation Ability

The information explored next was about student acceptance of technology-assisted learning, packaged in interactive multimedia. One form of implementing the use of ICT in the learning process was to use interactive multimedia that could be run through a computer device. A total of $30 \%$ of students stated "strongly agree" to develop an interactive multimedia application that could be applied to the learning process, followed by $63.3 \%$ of students who said "agree" to the development of interactive multimedia programs. Student responses increasingly signal that from the point of view of students' readiness in implementing ICT-assisted learning, they had readiness and very supportive responses to applying the ICT-assisted learning process. The following shows the table of questionnaire distribution results regarding student acceptance toward the information technology use in the learning process, packaged in an interactive multimedia. 


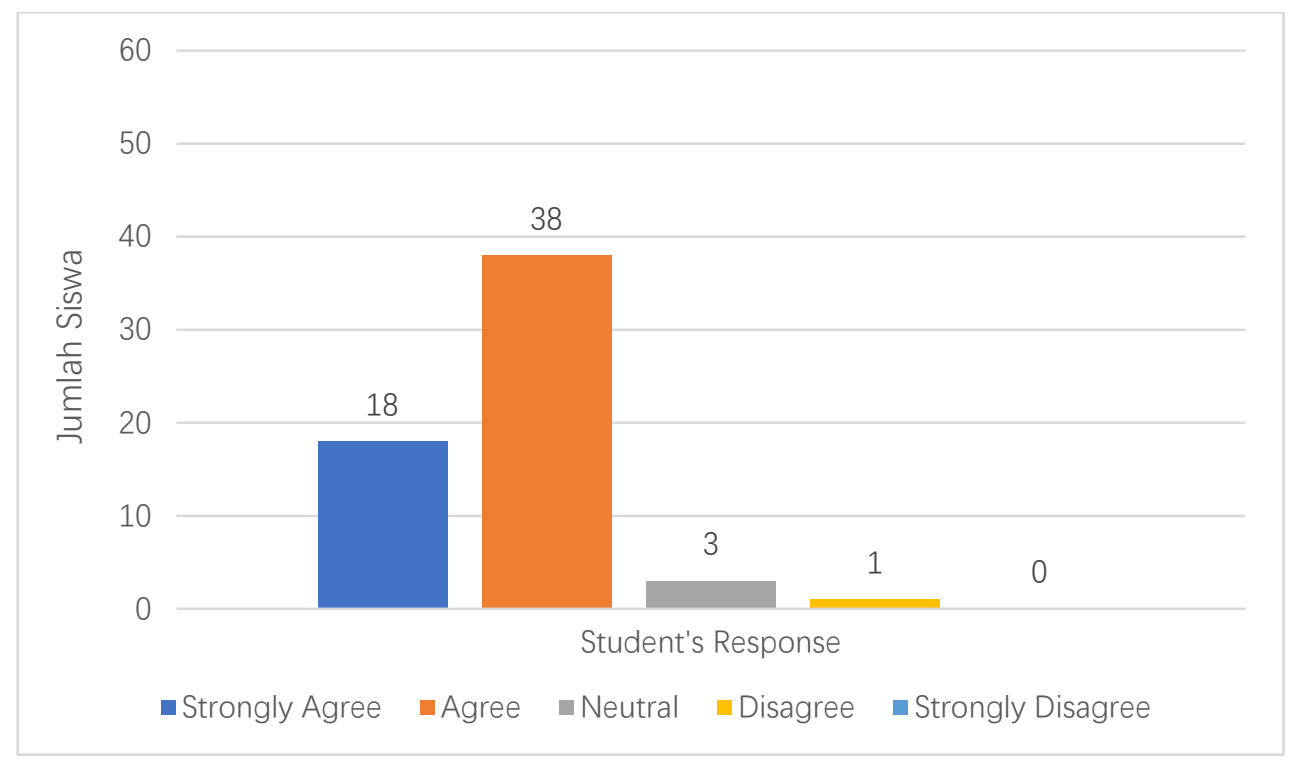

Fig 3. Student Acceptance toward Interactive Multimedia

\section{B. Discussions}

The purpose of this research is to basically identify the readiness of high schools in carrying out computer-assisted learning, with the indicators used in determining this readiness are asking questions to the teacher about readiness in implementing ICT-assisted learning, identifying student opinions regarding the availability of ICT-assisted learning support facilities. , the ability of students to operate computers, as well as students' views if an interactive multimedia learning is developed to be used in computer assisted learning as a supporting medium for the learning process.

Technology has great potential to improve the quality and academic results of the teaching process. Therefore, it is necessary to identify various kinds of problems and facts in the field related to teachers' ability, some of which may not be ready and some are ready to integrate technology [45]. The results showed that ICT application in learning had been supported by the availability of supporting facilities and infrastructure. Besides, students' ability as learning subjects in operating computers was included in the good category. The success of ICT-assisted learning or electronic-based learning, in fact, must be supported by infrastructure, materials, utilization systems, and policies that have been established as regulations, both by the government and schools [45,46]. Empirically, teachers have implemented technology-assisted learning, such as the use of presentation media and instructional videos, but in some cases, it is still necessary to develop the learning potentials or resources available in schools. Development needs to be done by teachers to make ICT-assisted learning even better. In particular, ICT will have a significant effect if implemented correctly in the learning process [47]. Besides, as a learning aid, ICT use can create more dynamic interactions between teachers and students. ICT also has benefits in providing visualization, which is more exciting and interactive regarding learning materials, as a learning aid and as a means of increasing teacher professionalism [47,48].

According to Gustina \& Wibowo [50], media or tools packaged in a computer-based digital format can affect learning achievement in students' affective and cognitive aspects. On the other hand, learning that begins to integrate ICT can also provide learning experiences to students. Sefriani et al. [51], in their research, also revealed that the use of interactive media or learning aids would be able to provide good results in learning, one of which could be realized by using computers in the learning process and collaborating with specific learning methods. Guan et al. [52] \& Ismail et al. [53] also explained the appearance of learning programs with ICT-based media formats, especially computers and smartphones packaged in a digital book application program [54], interactive multimedia [28,53], animated videos [56], game based learning [57] could display interactivity and motivate students to be enthusiastic about participating in the learning process, so students would tend to find it easier to achieve competency.

The use of digital technology in a school or educational institution can be implemented well through the support of several factors as described above. The use of ICT in learning activities is a must to improve student academic achievement $[7,55]$. The success of implementing digital technology into the learning process will significantly depend on the teachers' readiness and willingness to adopt technology, as well as teachers' understanding of the importance of ICT in the learning process in the digital era and during the pandemic currently hitting the world as it is today [27,56]. Through this technology, teachers can create a student-centered learning condition and make it easy for them to complete their work [60].

Indeed, teachers have a responsibility to be able to improve the quality of learning, and prevent the education system from being affected by global problems so that learning facilitated by technology becomes a real effort to improve the quality of the process and learning outcomes [61]. In fact, the current learning process, especially entering 
the era of the Covid-19 pandemic, has increased awareness of the use of technology in the education system [10]. Studies have shown that teachers and students are willing to use technology in the implementation of learning activities $[32,59,60]$. The use of technology in the learning process is able to provide positive results in achieving competence $[61,62]$.

On the other hand, one example of application development to support the implementation of ICT-assisted learning is interactive multimedia. Various kinds of research have been carried out and concluded that interactive multimedia influenced student academic achievement $[30,53,63,64]$ and could instill character values that are affective part of the achievement of learning goals [29].

Research on school readiness for implementing the use of ICT in the learning process is vital to note, considering the many benefits that can be obtained if ICT can be optimally implemented into the learning process. Hence, through the results on an educational institution's readiness regarding ICT use for the learning process, alternative and innovative ICT use in certain learning media can be formulated. It will have implications, either directly or indirectly, to achieve successful learning objectives.

\section{Conclusion}

Based on the identification results of school readiness in implementing information technology-assisted learning in senior high school, information was obtained that the school was in the ready category to carry out collaborative learning using information technology, especially the use of computers. The teachers' responses stated that $100 \%$ agreed that computer-assisted learning was interesting to be used as a learning innovation. Information was obtained that $55 \%$ of students stated that the school has already had a computer laboratory and other supporting facilities to implement the computer-assisted learning process, with the support of 60 computer units divided into two computer laboratory rooms. Then, the student competence was known to have abilities with a category of $18.3 \%$ 'very good', $41.7 \%$ 'sufficient', and $31.7 \%$ 'good' in operating programs or computer devices.

Even though it was included in the 'ready' category, senior high school can still optimize the facilities needed to implement computer-assisted learning. Referring to the research results, there are several improvements in the aspects of competence or computer mastery owned by teachers and students which still need to be improved. Thus, it can create a learning condition in the COVID-19 pandemic era as it is now better with the help of computer-based technology and applications. This research can be the basis for a follow-up that can be carried out by other researchers, namely the development of computer-based learning media products, or tracing the ability of teachers in developing applications or computer-assisted learning media, considering that these two things are determining factors for the success of computer-assisted learning and information communication technology (ICT).

\section{Acknowledgment}

Researchers would like to thank you for the guidance and direction given by Dr. Triana Rejekiningsih and Dr. Sudiyanto. With the direction and guidance given this research can be completed. In addition, thanks are also conveyed to the teachers and high school students who participated and were willing to be samples of this research.

\section{References}

[1] S. Ghavifekr, A. Razak, M. Ghani, N. Ran, Y. Meixi, and Z. Tengyue, "ICT Integration in Education: Incorporation for Teaching \& Learning Improvement.," Malaysian Online J. Educ. Technol., vol. 2, no. 2, pp. 24-45, 2014.

[2] F. Mikre, "The Roles of Information Communication Technologies in Education: Review Article with Emphasis to the Computer and Internet," Ethiop. J. Educ. Sci., vol. 6, no. 2, pp. 109-126, 2011, [Online]. Available: https://www.ajol.info/index.php/ejesc/article/view/73521.

[3] M. S. Z. B. A. Majid, M. M. B. A. Ali, A. A. B. A. Rahim, and N. Y. B. Khamis, "The Development of Technical English Multimedia Interactive Module to Enhance Student Centered Learning (SCL)," Procedia - Soc. Behav. Sci., vol. 67, pp. 345348, Dec. 2012, doi: 10.1016/j.sbspro.2012.11.337.

[4] O. Ojo and E. Adu, "The effectiveness of Information and Communication Technologies (ICTs) in teaching and learning in high schools in Eastern Cape Province," South African J. Educ., vol. 38, no. Supplement 2, pp. 1-11, Dec. 2018, doi: $10.15700 /$ saje.v38ns2a1483.

[5] F. A. Inan and D. L. Lowther, "Laptops in the K-12 classrooms: Exploring factors impacting instructional use," Comput. Educ., vol. 55, no. 3, pp. 937-944, Nov. 2010, doi: 10.1016/j.compedu.2010.04.004.

[6] S. Ghavifekr and W. A. W. Rosdy, "Teaching and learning with technology: Effectiveness of ICT integration in schools," Int. J. Res. Educ. Sci., 2015, doi: 10.21890/ijres.23596.

[7] Z. Hussain, "the Effects of Ict-Based Learning on Students' Vocabulary Mastery in Junior High Schools in Bandung," Int. J. Educ., vol. 10, no. 2, pp. 149-156, 2018, doi: 10.17509/ije.v10i2.7592.

[8] V. Motamedi, "The promises of presentational technology for teaching and learning," J. Educ. Learn., vol. 13, no. 3, pp. 416419, 2019, doi: 10.11591/edulearn.v13i3.13175.

[9] Nurjanah, D. Suryadi, J. Sabanda, and Darhim, "the Enhancement of Junior High School Students Computer-Based Interactive Multimedia Instruction,” Int. J. Educ., vol. 7, no. 2, pp. 111-119, 2014. 
[10] W. A. F. Dewi, "Dampak COVID-19 terhadap Implementasi Pembelajaran Daring di Sekolah Dasar," EDUKATIF J. ILMU Pendidik., vol. 2, no. 1, pp. 55-61, Apr. 2020, doi: 10.31004/edukatif.v2i1.89.

[11] pengelola web Kemdikbud, "Kemendikbud Terbitkan Pedoman Penyelenggaraan Belajar dari Rumah,” Jakarta, 28 Mei 2020 , 2020 .

[12] R. Waminton and S. Erlinawaty, "Problem-Based Mathematics Teaching Kits Integrated With Ict To Improve Students ' Critical Thinking Ability," Cakrawala Penididikan, vol. 34, no. 3, pp. 347-356, 2015.

[13] I. Acun and B. Karabulut, "ICT integration stages of teachers and factors affecting them," Energy Educ. Sci. Technol. Part B Soc. Educ. Stud., 2012.

[14] M. Nuur Wachid Abdul and S. Fuada, "E-Learning for society: A great potential to implement education for all (EFA) movement in Indonesia," Int. J. Interact. Mob. Technol., vol. 14, no. 02, pp. 250-258, 2020, doi: 10.3991/ijim.v14i02.11363.

[15] H. Jeong, C. E. Hmelo-Silver, and K. Jo, "Ten years of Computer-Supported Collaborative Learning: A meta-analysis of CSCL in STEM education during 2005-2014," Educ. Res. Rev., vol. 28, p. 100284, Nov. 2019, doi: 10.1016/j.edurev.2019.100284.

[16] C. R. Henrie, L. R. Halverson, and C. R. Graham, "Measuring student engagement in technology-mediated learning: A review," Comput. Educ., vol. 90, pp. 36-53, Dec. 2015, doi: 10.1016/j.compedu.2015.09.005.

[17] G.-J. Hwang, C.-M. Hung, and N.-S. Chen, "Improving learning achievements, motivations and problem-solving skills through a peer assessment-based game development approach," Educ. Technol. Res. Dev., vol. 62, no. 2, pp. 129-145, Apr. 2014, doi: 10.1007/s11423-013-9320-7.

[18] J. Sanchez, "The Generational Digital Gap within Dual Vocational Education and Training Teachers," Eur. J. Educ. Res., vol. 9 , no. 4, pp. 1557-1567, Oct. 2020, doi: 10.12973/eu-jer.9.4.1557.

[19] S. Putrawangsa and U. Hasanah, "INTEGRASI TEKNOLOGI DIGITAL DALAM PEMBELAJARAN DI ERA INDUSTRI 4.0," J. Tatsqif, vol. 16, no. 1, pp. 42-54, Aug. 2018, doi: 10.20414/jtq.v16i1.203.

[20] I. N. C. Mukti and H. Nurcahyo, "Pengembangan media pembelajaran biologi berbantuan komputer untuk meningkatkan hasil belajar peserta didik," J. Inov. Pendidik. IPA, vol. 3, no. 2, pp. 137-149, Oct. 2017, doi: 10.21831/jipi.v3i2.7644.

[21] Buchori, S. Rahmawati, and S. Wardani, "The Development of A Learning Media for Visualizing the Pancasila Values Based on Information and Communication Technology," J. Cakrawala Pendidik., vol. 36, no. 3, pp. 502-521, 2017, doi: 10.21831/cp.v36i3.12748.

[22] G. Gunawan, A. Harjono, and S. Sutrio, "Multimedia Interaktif dalam Pembelajaran Konsep Listrik bagi Calon Guru," J. Pendidik. Fis. dan Teknol., vol. 1, no. 1, p. 9, Mar. 2017, doi: 10.29303/jpft.v1i1.230.

[23] Y. S. Maharani, N. Suryani, and D. T. Ardianto, "Pengembangan Multimedia Pembelajaran Interaktif Pada Mata Pelajaran Pengolahan Citra Digital di Sekolah Menengah Kejuruan Negeri 8 Semarang," Teknodika, vol. 16, no. 1, p. 73, Mar. 2018, doi: 10.20961/teknodika.v16i1.34757.

[24] D. Churchill, "Educational applications of Web 2.0: Using blogs to support teaching and learning," Br. J. Educ. Technol., vol. 40, no. 1, pp. 179-183, Jan. 2009, doi: 10.1111/j.1467-8535.2008.00865.x.

[25] H. I. Yildirim and O. Sensoy, "The Effect of Science Teaching Enriched With Technological Applications on the Science Achievements of 7th Grade Students," J. Educ. Train. Stud., vol. 6, no. 9, p. 53, Jul. 2018, doi: 10.11114/jets.v6i9.3363.

[26] N. Sert and E. Boynueğri, "Digital technology use in ELT classrooms and self-directed learning," World J. Educ. Technol., vol. 8, no. 1, p. 51, May 2016, doi: 10.18844/wjet.v8i1.501.

[27] S. Z. Dewi and I. Hilman, "Penggunaan TIK sebagai Sumber dan Media Pembelajaran Inovatif di Sekolah Dasar," Indones. J. Prim. Educ., vol. 2, no. 2, pp. 48-53, Jan. 2019, doi: 10.17509/ijpe.v2i2.15100.

[28] A. N. N. Sholihah, I. Septiani, T. Rejekiningsih, Triyanto, and Rusnaini, "Development of interactive multimedia learning courseware to strengthen students' character," Eur. J. Educ. Res., vol. 9, no. 3, pp. 1267-1279, 2020, doi: 10.12973/eujer.9.3.1267.

[29] K. Komalasari and Rahmat, "Living values based interactive multimedia in Civic Education learning," Int. J. Instr., vol. 12, no. 1, pp. 113-126, 2019, doi: 10.29333/iji.2019.1218a.

[30] S. R. Manurung and D. D. Panggabean, "IMPROVING STUDENTS' THINKING ABILITY IN PHYSICS USING INTERACTIVE MULTIMEDIA BASED PROBLEM SOLVING," J. Cakrawala Pendidik., vol. 39, no. 2, pp. 460-470, Jun. 2020, doi: 10.21831/cp.v39i2.28205.

[31] N. M. Rusdin, "Teachers' Readiness in Implementing 21st Century Learning," Int. J. Acad. Res. Bus. Soc. Sci., vol. 8, no. 4, pp. 1293-1306, Jul. 2018, doi: 10.6007/IJARBSS/v8-i4/4270.

[32] H. Zyad, "Integrating Computers in the Classroom: Barriers and Teachers' Attitudes," Int. J. Instr., vol. 9, no. 1, pp. 65-78, Jan. 2016, doi: 10.12973/iji.2016.916a.

[33] T. Teo, "Factors influencing teachers' intention to use technology: Model development and test," Comput. Educ., vol. 57, no. 4, pp. 2432-2440, Dec. 2011, doi: 10.1016/j.compedu.2011.06.008.

[34] A. K. Hollman, T. J. Hollman, F. Shimerdla, M. R. Bice, and M. Adkins, "Information technology pathways in education: Interventions with middle school students," Comput. Educ., vol. 135, pp. 49-60, Jul. 2019, doi: 10.1016/j.compedu.2019.02.019.

[35] A. Nurdin, "Inovasi Pembelajaran Pendidikan Agama Islam di Era Information and Communication Technology," TADRIS J. Pendidik. Islam, vol. 11, no. 1, p. 49, Jun. 2016, doi: 10.19105/tjpi.v11i1.971.

[36] H. Hashim and Z. Tasir, "E-Learning Readiness: A Literature Review," in 2014 International Conference on Teaching and Learning in Computing and Engineering, 2014, pp. 267-271, doi: 10.1109/LaTiCE.2014.58.

[37] Y. Kondakci, K. Beycioglu, M. Sincar, and C. T. Ugurlu, "Readiness of teachers for change in schools," Int. J. Leadersh. Educ., vol. 20, no. 2, pp. 176-197, Mar. 2017, doi: 10.1080/13603124.2015.1023361.

[38] H. . Oketch, J. . Njihia, and A. . Wausi, "E-Learning Readiness assessment Model in Kenyas' Higher Education Institutions: A Case Study of University of Nairobi.," Int. J. Sci. Knowl., vol. 5, no. 6, pp. 29-41, 2014.

[39] V. Msila, "Teacher Readiness and Information and Communications Technology (ICT) Use in Classrooms: A South African Case Study," Creat. Educ., vol. 06, no. 18, pp. 1973-1981, 2015, doi: 10.4236/ce.2015.618202. 
[40] H. M. Azimi, "Readiness for Implementation of E-Learning in Colleges of Education,” J. Nov. Appl. Sci., vol. 2, no. 12, pp. 769-755, 2013.

[41] S. F. M. Alfalah, "Perceptions toward adopting virtual reality as a teaching aid in information technology," Educ. Inf. Technol., vol. 23, no. 6, pp. 2633-2653, Nov. 2018, doi: 10.1007/s10639-018-9734-2.

[42] N. Yue, "Computer multimedia assisted English vocabulary teaching courseware," Int. J. Emerg. Technol. Learn., vol. 12, no. 12, pp. 67-78, 2017, doi: 10.3991/ijet.v12.i12.7955.

[43] Sugiyono, "Metode Penelitian Kuantitatif, Kualitatif dan R \& D.Bandung:Alfabeta.," Metod. Penelit. Kuantitatif, Kualitatif dan R D.BandungAlfabeta., 2012, doi: 10.1017/CBO9781107415324.004.

[44] R. Yin, Case study research: Design and methods (5th ed.). Thousand Oaks, CA: Sage., 2013.

[45] H. Mubarak Al-Awidi and F. M Aldhafeeri, "Teachers' Readiness to Implement Digital Curriculum in Kuwaiti Schools," J. Inf. Technol. Educ. Res., vol. 16, pp. 105-126, 2017, doi: 10.28945/3685.

[46] R. Romero-Tena, L. Lopez-Lozano, and M. P. Gutierrez, "Types of Use of Technologies by Spanish Early Childhood Teachers," Eur. J. Educ. Res., vol. 9, no. 2, pp. 511-522, Apr. 2020, doi: 10.12973/eu-jer.9.2.511.

[47] O. M. Anwas, "Pemanfaatan Teknologi Informasi dan Komunikasi pada Pesantren Rakyat Sumber Pucung Malang," J. Pendidik. dan Kebud., vol. 21, no. 3, pp. 207-220, Dec. 2015, doi: 10.24832/jpnk.v21i3.187.

[48] H. Widyastono, "Pemanfaatan Teknologi Informasi dan Komunikasi pada Sekolah Menengah pertama Negeri Akreditasi A di Provinsi Jawa Timur,” J. Kwangsan, vol. 5, no. 1, pp. 21-38, Jun. 2017, doi: 10.31800/jurnalkwangsan.v5i1.37.

[49] G. A.Mammadova, F. T.Aghayev, and L. A. Zeynalova, "Use of Social Networks for Personalization of Electronic Education," Int. J. Educ. Manag. Eng., vol. 9, no. 2, pp. 25-33, 2019, doi: 10.5815/ijeme.2019.02.03.

[50] E. Gustina and M. Wibowo, "Improving Knowledge and Changing Health Attitude among Teenagers through Digital Media Flipbook," J. Educ. Sci. Technol., vol. 6, no. 1, p. 15, Feb. 2020, doi: 10.26858/est.v6i1.12136.

[51] R. Sefriani, I. Wijaya, M. Menrisal, and M. Dewi, "Testing Of The Validity of Interactive Learning Module on Creative and Entrepreneurs Learning Products,” J. Educ. Sci. Technol., vol. 6, no. 1, pp. 73-78, Mar. 2020, doi: 10.26858/est.v6i1.10277.

[52] N. Guan, J. Song, and D. Li, "On the Advantages of Computer Multimedia-aided English Teaching," Procedia Comput. Sci., vol. 131, pp. 727-732, 2018, doi: 10.1016/j.procs.2018.04.317.

[53] N. S. Ismail, J. Harun, M. A. Z. M. Zakaria, and S. M. Salleh, "The effect of Mobile problem-based learning application DicScience PBL on students' critical thinking," Think. Ski. Creat., vol. 28, pp. 177-195, Jun. 2018, doi: 10.1016/j.tsc.2018.04.002.

[54] A. Eladl and A. Al Musawi, "Effects of students attitudes towards using E- books on their self-efficacy and academic motivation," Eur. J. Educ. Res., vol. 9, no. 3, pp. 1167-1176, 2020, doi: 10.12973/EU-JER.9.3.1167.

[55] F. M. A. Khan and M. Masood, "The Effectiveness of an Interactive Multimedia Courseware with Cooperative Mastery Approach in Enhancing Higher Order Thinking Skills in Learning Cellular Respiration," Procedia - Soc. Behav. Sci., vol. 176, pp. 977-984, 2015, doi: 10.1016/j.sbspro.2015.01.567.

[56] A. S. Hapsari, M. Hanif, Gunarhadi, and Roemintoyo, "Motion Graphic Animation Videos to Improve the Learning Outcomes of Elementary School Students," Eur. J. Educ. Res., vol. 8, no. 4, pp. 1245-1255, Oct. 2019, doi: 10.12973/eu-jer.8.4.1245.

[57] R. Andrea and A. Nurhuda, "Developing Edu-Game 'Ulun Smart-Kid' Learning Media of Banjar Language and Game Agent with Finite State Machine Model," Int. J. Educ. Manag. Eng., vol. 10, no. 6, pp. 10-16, 2020, doi: 10.5815/ijeme.2020.05.02.

[58] J. Gil-Flores, J. Rodríguez-Santero, and J.-J. Torres-Gordillo, "Factors that explain the use of ICT in secondary-education classrooms: The role of teacher characteristics and school infrastructure," Comput. Human Behav., vol. 68, pp. 441-449, Mar. 2017, doi: 10.1016/j.chb.2016.11.057.

[59] R. Vanderlinde, K. Aesaert, and J. van Braak, "Institutionalised ICT use in primary education: A multilevel analysis," Comput. Educ., vol. 72, pp. 1-10, Mar. 2014, doi: 10.1016/j.compedu.2013.10.007.

[60] M. Hammond, L. Reynolds, and J. Ingram, "How and why do student teachers use ICT?," J. Comput. Assist. Learn., vol. 27, no. 3, pp. 191-203, Jun. 2011, doi: 10.1111/j.1365-2729.2010.00389.x.

[61] K. Erol and T. Danyal, "Analysis of distance education activities conducted during COVID-19 pandemic," Educ. Res. Rev., vol. 15, no. 9, pp. 536-543, Sep. 2020, doi: 10.5897/ERR2020.4033.

[62] J. W. Hur, D. Shannon, and S. Wolf, "An Investigation of Relationships Between Internal and External Factors Affecting Technology Integration in Classrooms," J. Digit. Learn. Teach. Educ., vol. 32, no. 3, pp. 105-114, Jul. 2016, doi: 10.1080/21532974.2016.1169959.

[63] M. Gellerstedt, S. M. Babaheidari, and L. Svensson, “A first step towards a model for teachers' adoption of ICT pedagogy in schools," Heliyon, vol. 4, no. 9, pp. 10-17, Sep. 2018, doi: 10.1016/j.heliyon.2018.e00786.

[64] J. A. Kumar, B. Muniandy, and W. A. J. Wan Yahaya, "Exploring the effects of emotional design and emotional intelligence in multimedia-based learning: an engineering educational perspective," New Rev. Hypermedia Multimed., vol. 25, no. 1-2, pp. 57-86, Apr. 2019, doi: 10.1080/13614568.2019.1596169.

[65] S. Abed, N. Alyahya, and A. Altameem, "IoT in Education: Its Impacts and Its Future in Saudi Universities and Educational Environments," in Advances in Intelligent Systems and Computing, 2020, pp. 47-62.

[66] J. Wang, T. Mendori, and T. Hoel, "Strategies for Multimedia Learning Object Recommendation in a Language Learning Support System: Verbal Learners Vs. Visual Learners," Int. J. Human-Computer Interact., vol. 35, no. 4-5, pp. 345-355, Mar. 2019, doi: 10.1080/10447318.2018.1543085.

[67] S. F. Simanjuntak, "Development of Interactive Multimedia Towards Economic Problems on Economic Subjects for Social Science Class X Students At Darma Yudha High School," Int. J. Educ. Best Pract., vol. 3, no. 2, p. 64, 2019, doi: 10.31258/ijebp.v3n2.p64-74. 


\section{Authors' Profiles}

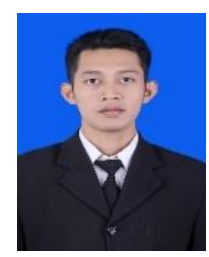

Mochamad Kamil Budiarto is a graduate student in the educational technology study program at Sebelas Maret University. Before continuing his studies, He successfully completed his undergraduate education in 2017, at the Educational Technology study program, in Yogyakarta State University. His research interest is in developing computer-based learning media, such as interactive multimedia to facilitate teaching and learning activities in schools.

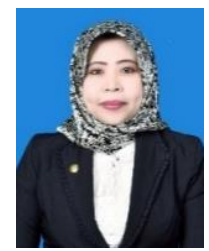

Triana Rejekiningsih has been working a lecturer in the Master of Educational Technology study program, Sebelas Maret University. She completed his doctoral education at the Indonesian Education University. She teaches e-learning and online learning courses and other subjects related to the use and development of digital media for learning. In addition, She focuses on his research, namely agrarian reform, educational technology, mobile-based learning media and character education whose publications can be found in various reputable journals both national and international.

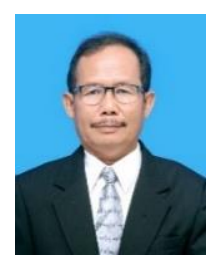

Sudiyanto is currently working as a lecturer in the Master of Education Technology study program, Sebelas Maret University. He completed his doctoral education at the Yogyakarta State University. He teaches learning and learning evaluation courses, systems approach, statistics, and relevant subjects in other study programs. In addition, He focuses on his research, namely learning evaluation, learning evaluation models, learning assessment in the affective, cognitive and psychomotor domains, as well as statistics for learning whose published works can be found in various reputable journals both nationally and internationally.

How to cite this paper: Mochamad Kamil Budiarto, Triana Rejekiningsih, Sudiyanto, " Implementation of Computer-assisted Learning in High School: Teachers and Students' Perspective", International Journal of Education and Management Engineering (IJEME), Vol.11, No.4, pp. 26-34, 2021. DOI: 10.5815/ijeme.2021.04.03 